\title{
NOVOS RUMOS DA TEORIA SOCIAL A PARTIR DE TRÊS GESTOS DA SOCIOLOGIA PRAGMÁTICA
}

\section{Diogo Silva Corrêa (iD}

E-mail: dioscorrea@gmail.com

Universidade de Vila Velha (UVV), Vila Velha - ES, Brasil.

DOI: $10.1590 / 3610505 / 2020$

\section{Introdução}

Em 1973, Gilles Deleuze publicou o texto "Em que se pode reconhecer o estruturalismo?", no qual fez um esforço de descrição dos elementos constitutivos das abordagens estruturalistas em voga à época. Em um gesto análogo, pretendo fazer, neste artigo, em um primeiro momento, uma breve e sintética exposição do que seria uma resposta à seguinte pergunta: em que se pode reconhecer a sociologia pragmática? Em seguida, pretendo mostrar como esse exercício de exposição teórica da sociologia pragmática ${ }^{2}$ tem menos um objetivo escolar de apresentação de uma "corrente" ou um "estilo" de se praticar a sociologia (Nachi, 2006; Benatoüil, 1999) - o que já foi feito, em parte, em outro artigo (Corrêa \& De Castro, 2016) -, e mais um esforço de introduzir novas

Artigo recebido em: 10/09/2019

Aprovado em: 09/03/2020 perguntas e apontar novos rumos para a agenda da teoria social contemporânea.

Neste sentido, busco incluir questóes nos debates da teoria social e da teoria sociológica - mas também no debate metateórico (Vandenberghe, 2013) -, que escapem ao que foi postulado pelo "novo movimento teórico” (Alexander, 1987). Assim, meu objetivo não é propriamente submeter à crítica figuras como Anthony Giddens, Jürgen Habermas, Pierre Bourdieu, Randal Collins e o próprio Jeffrey Alexander, mas sim apontar novos rumos para a teoria social, a partir de três gestos da sociologia pragmática.

\section{Os três gestos dentro de uma 'virada'?}

É sempre uma tarefa árdua e ingrata definir uma perspectiva teórica por elementos, tipologias e etiquetas. Comumente, como no caso das "viradas" (Bachmann-Medick, 2016), procura-se aquilo 
que a nova perspectiva promete e a imagem ou conceito-chave que sintetize o "novo" movimento. Na virada linguística, em sua versão habermasiana, por exemplo, é possível ver que ela promete uma saída da racionalidade instrumental denunciada pela primeira geração da Escola de Frankfurt, trazendo, ao mesmo tempo, a imagem de um mundo intersubjetivamente mediado, categorizado e em parte consensuado pelo filtro da linguagem. O seu conceito-chave é, como se sabe, a razão comunicativa (Habermas, 1984, 1987). A virada afetiva, de modo diferente, traz-nos a imagem mais imediata e direta do registro infralinguístico dos afetos, das emoçóes e das sensaçóes, e nos promete um elo mais vital e visceral na relaçáo entre sujeito e mundo. Os conceitos que ela traz para a linha de frente da teoria social são a "potência de agir" (Spinoza, 2007) e a "energia emocional” (Collins, 2004). Várias outras "viradas" poderiam ser evocadas - inclusive a pragmática, trazida por parte da sociologia francesa pós-bourdieusiana.

No entanto, em vez de uma "virada", dada por uma promessa, ideia ou imagem e um conceito-chave, evocarei três gestos constitutivos do que seja a sociologia pragmática. Primeiro, porque a noção de gesto (De Castro, 2016) traz imediatamente à imaginação um movimento em ato: por definição, ele sempre carrega consigo a ideia de um contorno, uma linha, e nunca um ponto, muito menos um ponto final. O gesto é sempre um fluxo movente que transita de um lugar a outro, em uma dinâmica de transitoriedade sem origem fixa ou fim delimitado. Em segundo lugar, mesmo o gesto "realizado", parado em um instante do tempo, não deixa de manter um contorno virtual que segue para além de si mesmo. $\mathrm{O}$ contorno que o gesto esboça delineia um caminho que vai além do ponto em que ele se encerra. Se isso é verdade, é levando às últimas consequências os contornos fundamentais esboçados pela sociologia pragmática que pretendo indicar uma nova direçáo retraçável para a teoria social. É neste sentido, que opto pela descrição de três gestos. Porém, quais seriam eles? Dito de outro modo, o que a sociologia pragmática trouxe de novo para o debate da teoria social?

Argumentarei, adiante, que o primeiro gesto que a sociologia pragmática traz à baila é o gesto metafísico de inversão da sociologia clássica durkheimiana. O que os sociólogos pragmáticos fazem é partir de uma ideia ou uma imagem do social (ou da sociedade) que seja a mais abrangente, ampla, inclusiva e desdeterminante possível pela nossa imaginação. Em outros termos, o primeiro gesto proposto pela sociologia pragmática é a definição do social pelo "princípio de liberalidade" ontológica (Garcia, 2014).

Há, com isso, uma espécie de novo jogo na teoria social, mais precisamente em torno do conceito de social, e que pode ser definido pelas seguintes perguntas: como pensar uma ideia de social que não exclua absolutamente nada a priori? Que esteja aberta para se pensar as mais heterogêneas e complexas composiçóes do que convencionamos chamar de sociedade? Como não reduzir o social ou a sociedade unicamente à ordem humana, de modo a incluir a extensão da humanidade aos animais? (Franco, 2015) Como incluir, no conceito de social, o papel dos objetos, dos dispositivos sociotécnicos, dos deuses, dos quark e das entidades náo humanas de modo geral? Busca-se, para tanto, um pluralismo ontológico de partida. No entanto, esse movimento coloca um outro problema: abrir maximamente os possíveis, liberar a priori toda e qualquer existência não resolve a questão de como conhecer aquilo que é pertinente para os atores que pesquisamos. A liberalidade ontológica do sociólogo deve corresponder a uma atenção particular às determinações e definições que os atores produzem acerca de si mesmos e do mundo. Eis a importância do segundo gesto.

Trata-se de um gesto epistemológico de delegação, aos atores ou actantes, dos critérios de definição do que é pertinente, justo, real, verdadeiro, autêntico, etc. Em vez de uma ruptura epistemológica com o senso comum, como apregoavam Bourdieu, Passeron e Chamboredon (1973), objetiva-se, neste segundo gesto, uma delegação radical. Importa, aqui, restituir, no limite do possível, o universo expresso pelas definiçóes dos atores e pelo poder de agência das entidades não humanas. O pluralismo de possíveis do primeiro gesto deve corresponder à abertura radical para a experiência concreta daqueles e daquilo (já que os não humanos devem estar incluídos) que se deseja pesquisar e conhecer.

Pretende-se, com isso, não apenas colocar a experiência dos atores e a "actância" (Latour, 2001) 
das entidades não humanas como o ideal regulativo do conhecimento do pesquisador, mas fazer de suas experiências e da própria actância um dispositivo de permanente desestabilização dos conceitos e conhecimentos prévios da sociologia, da antropologia, da filosofia, ou de qualquer outro saber que corresponda ao arcabouço conceitual inicial do pesquisador. Porém, é preciso reconhecer que uma liberação radical dos possíveis, uma delegação máxima do que, em ato, mostra-se efetivamente "real" na experiência dos atores e na actância das entidades não humanas, não garante uma boa teoria social. É imperativo centrar-se nas situaçóes ou nos momentos em que a experiência dos atores e a actância de entidades não humanas tendem a autoexplicitar-se.

Daí a necessidade de um terceiro gesto, que chamo de gesto metodológico de seleção e enquadramento de situações ou momentos indeterminados, para aqueles ou aquilo que se deseja conhecer. Aqui, trata-se do que se pode chamar de uma heurística das indeterminaçóes (Peters, 2017), dos momentos críticos (Boltanski \& Thévenot, 1991; Chateauraynaud, 1991), das situaçóes problemáticas (Cefaï, 2018), das controvérsias (Latour, 2015; 2016), dos casos (affaires) (Boltanski \& Clavérie, 2007), dos alertas (Chateauraynaud \& Torny, 1999), etc. Tal enquadramento metodológico, que busca se concentrar nos momentos, situações ou ocasiôes indeterminados, é justificado pelo fato de aquilo que é constitutivo, fundamental, elementar e essencial para os atores pesquisados tender a ser explicitado por eles e, por derivação, para o pesquisador.

\section{O primeiro gesto: inversão metafísica}

Comecemos pelo primeiro ponto: qual seria esta inversão da sociologia clássica durkheimiana? Ela se daria em quais termos? Como toda obra clássica, há uma multiplicidade de entradas e abordagens possíveis da sociologia de Émile Durkheim. No presente artigo, importa enfatizar o modo como o pai fundador da sociologia francesa traz para o universo sociológico aquilo que, na filosofia, Kant chamou de "argumento ontológico" (Crahay, 1949). Contudo, antes de apresentar tal argumento, como também o modo como ele foi incorporado à sociologia por Durkheim, enfatizo apenas que sua exposição cumpre o objetivo estratégico de tornar mais nítida, por contraste, a radicalidade da inversão feita pela sociologia pragmática. Usando a obra de Latour, explicito como se dá a transição do social mais potente e determinante (expresso pelo conceito durkheimiano de sociedade) àquele que é mais fraco e maximamente ligado à ideia do "deixar ser” (expresso pela noção de associação latouriana).

\section{$\mathrm{O}$ argumento ontológico}

O primeiro a elaborar o argumento ontológico na filosofia foi Santo Anselmo. No livro Proslogion (1986), traduzido em inglês como "Discurso sobre a existência de Deus", o pensador medieval procura "um argumento único que não tenha necessidade a não ser de si mesmo para se provar e para garantir que Deus existe verdadeiramente" (p. 229). No argumento construído pelo autor, Deus é definido como ens quo maus cogitari non potest; isto é, o ser tal, que nada maior do que Ele possa ser pensado. Ora, reflete Santo Anselmo: se Deus existe ao menos como ideia - e se a ideia afirma que Ele é o maior ser possível -, isto implica que, para ser efetivamente o maior, Ele não pode existir apenas como ideia, posto que um ser que existisse tanto como ideia, quanto na realidade, seria maior do que aquele que existisse somente como ideia. Portanto, se realmente existe algo de que não se pode conceber algo maior, esse algo deve necessariamente existir na inteligência, como conceito, mas também fora dela, no mundo.

Quem retoma o argumento de Anselmo - e possui particular influência sobre Durkheim - é o filósofo moderno René Descartes. Traduzindo tal argumento em seus próprios termos, ao invés de definir Deus como o "maior ser que se pode conceber", Descartes o define, na quinta meditação (AT, IX, 52), como o "ser soberanamente perfeito". Assim, em vez de uma definição negativa e comparativa de Deus, como em Anselmo, ele oferece uma definição positiva (a perfeição) e absoluta (soberanamente perfeito). É com base na ideia de perfeição, que Descartes assevera a prova ontológica: "Deus é o ser soberanamente perfeito; ora, a existência é uma perfeição; logo, Deus existe". Se Deus é aquele dotado de perfeição - e se a existência de Deus é perfeita -, sabe-se, segundo Descartes, que existir é melhor do que não existir, que ser é 
melhor do que não ser. Logo, para o filósofo francês, é logicamente indubitável a existência de Deus.

\section{O argumento ontológico em Durkheim}

Se diversas abordagens que fazem a associação entre a sociologia de Durkheim e a filosofia costumam sublinhar como ele "sociologiza" o sujeito transcendental kantiano - o que, com efeito, está expresso na introdução e na conclusão de sua obra As formas elementares da vida religiosa ([1912] 1968) -, chamo atenção para como esta pode ser lida como uma espécie de sociologização do argumento ontológico - e também, por corolário, como uma ontologização do argumento sociológico. ${ }^{3}$

Vimos o que seria propriamente o argumento ontológico na filosofia, o qual pode ser resumido a partir da seguinte questão: de que maneira o pensamento pode encontrar em si mesmo os recursos suficientes para chegar à ideia de que há alguma coisa ou um ser que seguramente existe? A resposta à referida questão consistiu na busca por um ser que é de tal modo grande (Santo Anselmo), perfeito (Descartes) e necessário (Leibniz), que, mesmo se fosse possível negá-lo pelo pensamento, ele se imporia por conta própria. $\mathrm{Na}$ filosofia, este objeto privilegiado seria Deus. Como vimos, Ele foi tomado como o ser superior, cuja potência é de tal modo forte que, mesmo quando negado, Ele tanto se imporia por si mesmo, como englobaria aquilo que a Ele se opóe.

Como, então, Durkheim transpóe o argumento ontológico para a sociologia? É possível afirmar que, ao longo de sua obra, boa parte de seus esforços teóricos concentra-se na busca por um ser que seguramente existe, uma espécie de incondicionado da vida social. ${ }^{4}$ Este, como veremos, não é mais o Deus dos filósofos clássicos, mas a própria sociedade. E a maneira como Durkheim incorpora o argumento ontológico exprime-se de modo particularmente nítido no modo como ele se esforça em comprovar que a sociedade é um fato; que ela existe. Como sustenta o filósofo Giovanni Paoletti (2012, p. $207-$ 244), Durkheim estabelece ao menos cinco provas da existência da sociedade.

A primeira está diretamente atrelada ao axioma muito utilizado por ele, segundo o qual "nada vem do nada" (ex nibilo nibil fut) e "a vida coletiva não nasceu da vida individual, mas é, ao contrário, a segunda que nasce da primeira" (Durkheim, 1991[1893], p. 264). Com isso, o autor mostra como um indivíduo não poderia se elevar acima de si mesmo, a não ser em presença de uma instância que lhe fosse superior: "nada vem do nada, e o indivíduo abandonado à própria sorte não poderia se elevar acima de si mesmo" (Durkheim, 1950, p. 124). Um corolário dessa ideia diz respeito à relação entre causa e efeito: segundo Durkheim, o axioma "nada vem do nada" implica na consideração do fato de que é logicamente necessário que a causa seja maior que o efeito. Para exemplificar o seu raciocínio, ele utiliza como exemplo o poder do Estado (Durkheim, [1893]1991, p. 50-51). A função estatal consistiria em defender a consciência comum contra as forças antagonistas e individuais que podem a ele se contrapor. O que efetivamente dota o Estado de estabilidade e força extra náo pode advir dos indivíduos, na medida em que, nesse caso, o efeito seria maior que a causa. A superioridade do Estado - e da sociedade - não pode ter como fonte senão "a força que é imanente à consciência comum” (p. 51). A força superior que caracteriza a consciência comum não tem como origem os indivíduos (que são menores do que ela), mas sim a força coletiva. Eis porque Durkheim inverte o raciocínio dos individualistas e delineia uma primeira prova ontológica da sociedade: "a vida coletiva não nasceu da vida individual, mas, ao contrário, a segunda é que nasceu da primeira” (p. 263).

A segunda prova proposta por Durkheim é atrelada à noção de autoridade, pois se o primeiro postulado ("nada vem do nada") introduz a necessidade da existência de algo superior aos indivíduos, o segundo deve conferir uma maior facticidade ao modo de existência dessa realidade superior. Ela existe de fato? Se sim, qual é o seu modo de manifestação ou de aparição?

Para Durkheim, a autoridade é a maneira pela qual o social se faz presente na sua dimensão exterior e, sobretudo, coercitiva. É ela que permite supor a existência de uma força ou potência superior àquela dos indivíduos, que, mesmo quando contrariada, impóe-se a eles. Por exemplo, quando alguém é investido do papel social de irmão, marido, cidadão, ou - para lembrar a famosa descrição de Sartre - 
garçom de café, a pessoa tende a se adaptar e se ajustar, pela própria força das coisas, aos códigos de comportamento definidos previamente fora de sua mente. ${ }^{5}$

Estes dois argumentos de Durkheim indicam a presença de uma base ontológica da sociedade. Eles mostram que ela simplesmente existe. No entanto, há ainda uma terceira forma de exprimir a sua existência ou entidade suprema. No livro O Suicídio (1897), Durkheim pretende demonstrar os resultados concretos que podem ser alcançados pelo uso dos métodos que propõe para conhecer a sociedade. No primeiro capítulo do livro II (p. 245-263), ele introduz uma nova forma de apreensão e de comprovaçáo da sociedade - muito utilizada, posteriormente, por exemplo, por Bourdieu, em diversas obras: a estatística. Nesse mesmo livro, Durkheim correlaciona a prova empírica da existência $\mathrm{da}$ sociedade às regularidades estatísticas.

Durkheim também mobiliza o argumento do sentimento coercitivo, muito utilizado na Introdução das Regras do método sociológico (1999[1895]), ao se referir à religião e à moral. Temos, aqui, o quarto argumento que comprova ontologicamente a existência da sociedade: ao falar das representaçôes de forças superiores (pessoais ou abstratas) e, por isso mesmo, imperativas, ele afirma que a causa ou o objeto da representação "deve existir em alguma parte fora do indivíduo". O que seriam esse objeto ou causa fora da esfera individual? Quando pensamos na filosofia clássica, ou no que Durkheim chama de imaginação do senso comum, trata-se de Deus; para a ciência da sociologia, defendida pelo autor, e que, segundo ele, atém-se às realidades observáveis, é a sociedade. ${ }^{6}$

Há, ainda, um quinto elemento ao qual Durkheim faz referência para comprovar a existência da sociedade, concernente à relação entre esta e o sentimento da existência da divindade. Ainda que tal sentimento possa ser o produto da imaginaçáo dos povos que acreditam em forças divinas (e sua pluralidade de formas de aparição e de expressão mostra a variabilidade cultural e social dessas manifestações), tudo aquilo que é religioso possui, para Durkheim, um poder real, uma autoridade concreta, conforme expresso na seguinte passagem:

De uma maneira geral, não há dúvida de que uma sociedade tem tudo o que é preciso para despertar nos espíritos, pela simples ação que exerce sobre eles, a sensação do divino; pois ela é para seus membros o que um Deus é para seus fiéis. Com efeito, um Deus é antes de tudo um ser que o homem concebe, sob certos aspectos, como superior a si mesmo, edo qual acredita depender [...] a sociedade provoca em nós a sensação de uma perpétua dependência. Por ter uma natureza que lhe é própria, diferente da nossa natureza de indivíduo, ela persegue fins que lhe são igualmente específicos, mas, como não pode atingi-los, a não ser por intermédio de nós, reclama imperiosamente a nossa colaboração. Exige que, esquecidos de nossos interesses, façamonos seus servidores e submete-nos a todo tipo de aborrecimentos, privaçóes e sacrifícios, sem os quais a vida social seria impossivel. É assim que a todo instante somos obrigados a sujeitar-nos a regras de conduta e de pensamento que não fizemos nem quisemos, e que, inclusive, são às vezes contrárias às nossas inclinaçóes e nossos instintos mais fundamentais. (Durkheim, [1912]1968, p. $284-5)^{7}$

Na sociologia posterior à de Durkheim, duas são as formas de inversão deste argumento metafísico. Uma primeira via, sobre a qual não me deterei, pode ser denominada de uma inversão moral, feita por Pierre Bourdieu. ${ }^{8}$ No entanto, para além dessa inversão de ordem moral da sociedade, cuja onipotência divina se mantém, mas ao preço da introdução da ardilosidade de um gênio maligno, pode-se dizer que há também uma outra inversão possível, aquela que considero própria ao primeiro gesto da sociologia pragmática. Nela, não se trata mais de definir, como em Durkheim, o ser mais forte, mais potente e maior que se impóe àquilo que pode inclusive tentar negá-lo. Em vez disso, trata-se de fazer uma verdadeira inversão desse princípio, que visa definir um sentido do social mais fraco, mais dessubstancializado e, por isso mesmo, o mais plástico possível.

Tal ideia já se encontra presente nas primeiras reflexóes metafísicas de Bruno Latour, que podem ser lidas na última parte de seu famoso livro Pasteur: Guerre et paix des microbes (Latour, 1984). Neste pequeno e curto tratado, o autor francês expóe as diretrizes de seu projeto de metafísica experimental 
e estabelece "uma espécie de mínimo vital, de 'SMIG metafísico" (p. 119), definido como princípio de irredução. ${ }^{9}$ Em uma escrita ao modo da Ética, de Espinosa, Latour afirma que "nada é, por si mesmo, redutível ou irredutível a qualquer outra coisa”. Assim, no lugar de uma metafísica geral que advoga por uma grande macro-unidade (Deus ou a sociedade), ele assume um pluralismo metafísico que encoraja a proliferação de tantos objetos, atores e actâncias ou agências, o universo - ou melhor, o pluriverso - for capaz de reunir. ${ }^{10}$ Com isso, a ambição de Latour é mostrar, primeiro, como a sociedade não é o ser aristocrático que define todos os outros, mas sim uma entidade entre outras, que emerge das entredefinições dos atores. É neste sentido, que há uma espécie de democracia ontológica radical de partida: se há diferenças entre as entidades e as actâncias, elas são permanentemente feitas e refeitas, por meio de provas (épreuves) e de experimentações. ${ }^{11}$

Consequente com esse princípio de irredução, Latour bane o grande ser ou o Uno, e propóe uma "ontologia plana"12 (De Landa, 2002), na qual todos as entidades e agências são tratadas a priori em um mesmo nível, e, portanto, dotadas de um mesmo estatuto de realidade. Em uma lógica oposta àquela da sociedade durkheimiana, ele defende, assim, uma imanência radical, na qual não há ser transcendente: se a sociedade existe - e ela existe -, ela não é mais o Ser determinante, mas apenas mais uma entidade ou actância, entre tantas outras.

No entanto, é sobretudo no livro Reagregando o social (Latour, 2012), que Latour extrai as implicaçóes de sua metafísica "irreducionista" para a teoria social, desenvolvendo melhor a ideia de uma sociologia das associações. $\mathrm{Na}$ introdução da obra, o ex-professor da École de Mines afirma que o social não é uma substância ou "um tipo de material" como "madeira", "aço", "biológico", "linguístico", mas apenas "um tipo de conexão" (p. 23), "um movimento peculiar de reassociação e reagregação” (p. 25). Para Latour, não se deve mais pensar $o$ social (substantivo), nem em alguma coisa de social (adjetivo), mas em tudo o que se dá, digamos assim, (as)sociadamente (como advérbio). É neste sentido, que ele defende uma sociologia "associal"; uma sociologia das associaçóes, em que "o social parece diluído por toda parte e por nenhuma em particular” (p. 19).

Nessa outra abordagem proposta, Latour se pergunta o que vem a ser o "social" ou a "sociedade". $\mathrm{Na}$ sociologia do social, de tipo durkheimiano, cujos pressupostos ele critica, postula-se a "existência de um tipo específico de fenômeno chamado por vários nomes: 'sociedade', 'ordem social', 'prática social'; dimensão social' ou 'estrutura social'” (p. 19). Em suma, estima-se, nessa visão, a existência de fenômenos que são intrinsicamente sociais, e a sociedade é, como vimos em Durkheim e em Bourdieu, "uma esfera específica da realidade” (p. 20). Na outra acepção, aquela que inverte a metafísica durkheimiana e pela qual Latour advoga, "não há nada de específico na ordem social", e o social "é aquilo que outros tipos de conectores amalgamam” (p. 22). Nessa via, social é tudo aquilo que designa apenas "uma série de associações entre elementos heterogêneos”; razão pela qual a sociologia deixa de ser a ciência que vai definir o social ou o que é a sociedade (como em Durkheim), e passa a ter uma tarefa um tanto mais modesta: a "busca de associaçóes" (p. 23). Ora, se tudo que é associável é social, logo o objeto da sociologia pode ser "significar qualquer tipo de agregado, de ligaçóes químicas a vínculos jurídicos, de forças atômicas a corporaçóes, de organismos fisiológicos a partidos políticos" (p. 23).

Segundo esta sociologia, ou melhor, "associologia", a tarefa do sociólogo não mais consiste em explicitar - como em Durkheim - uma instância aristocrática última, capaz de hierarquizar (ou de se impor a) todos os outros seres, mas sim em instituir um plano maximamente democrático, capaz de colocar todos os seres, em princípio, em pé de igualdade. No lugar do aristocratismo durkheimiano, calcado na potência máxima do social, Latour advoga por uma democracia ontológica baseada na plasticidade radical das associaçôes e no seu princípio de "irredução". ${ }^{13}$

No entanto, uma vez explicitado este primeiro gesto, um problema se revela logo de imediato. Entendemos bem que, enquanto pesquisadores, sociólogos ou antropólogos, devemos a priori estipular um conceito do social o mais desdeterminado e desdeterminante possível, levando o princípio de liberalidade à sua máxima potência. Por outro lado, 
é evidente que os próprios atores que pesquisamos, não param incessantemente de definir, redefinir, determinar e transformar o que lhes parece pertinente, justo, real, verdadeiro, autêntico, etc. Além disso, o próprio mundo dos não humanos não deixa de, a todo momento, falar através das suas agências e actâncias. Por isso, a desdeterminação de partida do sociólogo deve corresponder à atenção radical e a um ímpeto descritivo e explicitador das determinaçóes, definiçóes, critérios, actâncias e agências produzidas constantemente pelos próprios atores (humanos e não humanos) que ele deseja conhecer.

\section{O segundo gesto: da ruptura à delegaçáo}

No famoso Le métier de sociologue (Bourdieu, 1973), Pierre Bourdieu, Jean-Claude Chamboredon e Jean Claude Passeron defendem - seguindo a tradição de Gaston Bachelard e de Durkheim - que o "primeiro obstáculo epistemológico" (Bachelard, 1993[1938], p. 23-54) a ser suplantado, por toda sociologia que se pretenda uma ciência rigorosa, é a adesão impensada do sociólogo às pré-noçôes do senso comum e às suas explicaçóes espontâneas. Segundo tal tradição, a sociologia deve necessariamente romper com o objeto imediato do conhecimento e impor a si mesma, como primeiro imperativo, a "ruptura epistemológica” (Bachelard, 1986[1949], p. 104) com o senso comum (doxa). Este ato serve para que o conhecimento por ela produzido seja alçado à condição de concepção científica acerca do social.

Bourdieu e seus colegas afirmam, no aludido tratado de epistemologia científica, que para a boa sociologia, o "fato científico" deve ser "conquistado, construído e verificado". (Bourdieu et al., 1973, p. 24, 81). Por conseguinte, o bom conhecimento produzido pela ciência deve estar submetido à sua conquista contra o senso comum e à sua construção, a qual, em ruptura com as concepçóes espontâneas do social, deve atender a princípios de verificaçóes posteriores. Porém, qual seria a outra possibilidade para além daquela estipulada por esses autores? Eis aqui a importância do segundo gesto fundamental, "em que se pode reconhecer um sociólogo pragmático": o gesto de delegação. Ele consiste, primeiro, no ato de colocar entre parênteses todos os critérios de definição do que é pertinente, justo, real, verdadeiro etc. Em um segundo momento, consiste em delegar tal tarefa aos atores que se está pesquisando.

Recentemente, quem melhor definiu o gesto de delegação foi Gildas Salmon (2016, p. 41-60), em seu artigo sobre a "virada ontológica", na antropologia. Embora sua discussão seja centrada no discurso antropológico, o primeiro exemplo de delegação a que o autor faz referência é, não por acaso, encontrado na sociologia pragmática de Boltanski e Thévenot. Ao dissertar sobre o procedimento de delegação, Salmon diz que

A primeira instância que me vem à mente no contexto francês é o que ocorreu na sociologia em torno de Luc Boltanski, com a substituição de uma 'sociologia crítica' por uma 'sociologia da crítica'. Esse caso ilustra claramente o que está implicado na noção de delegação. Quando uma operação torna-se excessivamente onerosa para o sociólogo ou o antropólogo continuar perseguindo de uma maneira exclusiva ou soberana, ele a delega aos atores, dando à pesquisa um novo ímpeto: ao invés de dar uma interpretação crítica das práticas dos atores, o escopo torna-se agora descrever como estes últimos criticam e, a partir disso, torna-se também formalizar os modelos a que os atores se referem em seus atos de denúncia. (Salmon, 2016, p. 42)

Com efeito, ao fazerem a passagem de uma sociologia, que arroga para si o monopólio da produção da crítica social, para uma sociologia, que toma as operaçóes críticas dos atores como objeto de análise, Boltanski e Thévenot (1991) realizam esse movimento de delegação no plano axiológico. Em De la justification, os dois autores abrem mão de definir o mundo social com base em um princípio único, seja ele de justiça (Rawls) ou de dominação (Bourdieu); e, em vez disso, delegam aos próprios atores pesquisados tal poder de definição do que seria o justo ou injusto, do que merece ser considerado "grande", digno de valor, e do que se evidencia por sua pequeneza ou mesquinhez.

É com base nesse pressuposto, que Boltanski e Thévenot propóem uma pragmática dos julgamentos 
ordinários, que visa formalizar a pluralidade de concepçóes de justo imanentes às críticas e justificaçóes expressas, em momentos críticos, pelos próprios atores pesquisados. (Corrêa \& De Castro, 2016). Tal movimento pressupóe, por sua vez, um ato anterior por parte dos sociólogos; a saber, que eles coloquem suas pressuposiçóes normativas entre parênteses, para, com isso, abrirem-se ao senso de justiça daqueles que desejam conhecer. No caso particular da mencionada obra, De la justification (1991), tratou-se de uma delegação específica: uma delegação aos atores dos critérios axiológicos de definição do justo (Heinich, 1998, p. 71-82).

É curioso que Salmon verse sobre a delegação ontológica, mas não avance em exemplos existentes a esse respeito na própria sociologia pragmática. Ele não indica, na sociologia francesa de sensibilidade pragmatista subsequente àquela de Boltanski e Thévenot, os autores que deslocam o gesto delegativo na direção da ontologia. Seus exemplos, após a menção ao trabalho de Luc Boltanski, ficam restritos à antropologia, mais precisamente a autores como Claude Lévi-Strauss, Marylin Strathern e Eduardo Viveiros de Castro. No entanto, na própria sociologia pragmática, notadamente naquela proposta por Francis Chateauraynaud, um antigo aluno de Boltanski, foi realizada a referida passagem de uma delegaçáo axiológica para uma efetiva delegação ontológica.

A importância do livro Experts et faussaires, escrito por Chateauraynaud em coautoria com Christian Bessy (1995), consiste justamente em manter o gesto delegativo, mas operando uma transição do universo axiológico da justiça para o universo ontológico da realidade, delegando aos atores pesquisados a capacidade de produzir a própria definiçáo do que seja o real. Há que se dizer que, na filosofia pragmatista americana de William James, já existe um deslocamento desse gesto delegativo na direção da ontologia. Não é por acaso que Erving Goffman, em seu famoso livro Frame Analysis (1974), abre a ontologia ao gesto delegativo, o que é expresso em seu comentário a respeito do pensamento de William James

Em lugar de interrogar-se sobre o que é a realidade, ele [William James] deu ao assunto uma guinada fenomenológica subversiva, colocando em itálico a seguinte pergunta: em que circunstâncias pensamos que as coisas são reais? $\mathrm{O}$ importante acerca da realidade, segundo ele, é a impressão que temos de seu caráter real, em contraposição ao sentimento que temos de que algumas coisas não têm esta qualidade. Alguém pode, então, se perguntar em que condiçôes se produz esse sentimento, e esta pergunta está ligada a um problema pequeno e administrável, que tem a ver com a câmera, e não com aquilo que a câmera fotografa. (Goffman, 2012, p. 24)

Ao pensar não tanto no real, ou sobre o que ele é - ou como a sociologia pode definir a realidade, para além daquilo que os próprios atores definem como real -, mas "em que circunstâncias" ou condições as pessoas pensam "que as coisas são reais", James e Goffman abrem a possibilidade de incluir o gesto delegativo no plano da ontologia. Assim, eles quebram com as sociologias que, em ruptura (epistemológica) com o senso comum, pretendem fundamentar um plano objetivo de realidade maior do que aquele promulgado pelas concepçôes espontâneas dos atores pesquisados. E é justamente esta a questão do livro Experts et faussaires. Partindo das investigaçóes empreendias pelos atores para atestar a autenticidade dos objetos e, sobretudo, a facticidade das coisas, Chateauraynaud e Bessy analisaram uma ampla gama de casos, dentre os quais a "falsificação de marcas, polêmicas sobre patentes e direitos autorais, cenas de estimação [do valor de objetos], de narrativas de colecionadores, controvérsias históricas ou arqueológicas, plágios ou farsas literárias, controvérsias em torno de atribuição de autoria de quadros ou casos de degustação". (Chateauraynaud \& Bessy, 1995, p. 17)

A ideia dos autores, no referido livro, foi colocar entre parênteses a sua própria concepção do que seria a realidade ou o real, e buscar entender os critérios utilizados pelos próprios atores pesquisados para definir o seu regime de distribuiçáo do real e do falso, do autêntico e do inautêntico. Com isso, ambos analisaram a economia da percepçáo mobilizada pelas pessoas, quando elas buscavam não tanto produzir um acordo justo - como interessava a Boltanski e Thévenot, em De la justification -, mas uma realidade sensível e tangível compartilhada e comum (Chateauraynaud, 
1997). Ao atribuírem, no gesto delegativo, um primado da experiência dos atores a respeito da (ou do que seja a) realidade, eles procuraram dar visibilidade ao modo como, em situaçóes particulares em que as coisas são postas à prova, os próprios atores atestam a facticidade do mundo.

É bem verdade que os exemplos poderiam ser mais numerosos, a partir de outros autores da própria sociologia pragmática. No entanto, penso que os já citados são suficientes para expressar o segundo gesto, que, em contraposição à ruptura epistemológica com a experiência dóxica do senso comum (como em Bourdieu e Durkheim), pode ser chamado de gesto epistemológico de delegação. Grosso modo, ele consiste em dizer que o conhecimento do mundo pertinente - ou o conhecimento do que é pertinente no mundo não é e nem pode ser aquele previamente estabelecido pelo sociólogo, mas sim deve ser mostrado em ato pelos próprios atores. Neste sentido, trata-se de um princípio de abertura radical às experiências dos atores, fazendo com que todo sistema conceitual, por mais bem elaborado que seja, não deixe de reformular-se permanentemente à luz da experiência dos atores que o pesquisador deseja conhecer.

\section{O terceiro gesto: da indeterminaçáo tomada como dada à heurística dos momentos críticos}

Em suas reflexóes sobre o mundo da vida, a sociologia fenomenológica de Alfred Schütz nos ensinou que há, desde sempre, um mundo que nos é disponível e nos antecede, e que funciona como um esquema de referências tipificadas que podemos mobilizar. Desde que somos “jogados” (Heidegger) no mundo e começamos a nos tornar conscientes dele, percebemos que há um modo originário prático de agir, habitual e rotineiro, em que a reflexão e o pensamento se encontram diluídos na ação prática. Esta forma elementar da experiência quotidiana - tematizada também por Goffman (1992) e Garfinkel (1967) é visível, quando percebemos que a maior parte de nossas açóes são guiadas pela experiência imediata e intuitiva, sem a necessidade de, a todo momento, submetermos o que fazemos à peneira das verificações incessantes.

Nessa modalidade prática de agir no mundo, as entidades com as quais nos deparamos - em particular, e com o mundo, de modo geral - possuem uma forma de aparição própria; isto é, apresentam-se na qualidade dóxica e nos são naturalmente anuídas e ratificadas, de modo tácito, por nossas percepçóes. Garfinkel (1963, p. 210-213), melhor do que qualquer outro autor, arrolou certos atributos comuns a essa forma singular de agir e estar no mundo. Estes seriam: (1) reciprocidade de expectativas em relação ao modus operandi dos objetos materiais e dos sujeitos humanos; (2) ausência de desconfiança a respeito das situaçóes em que estamos envolvidos em nossos contextos práticos de ação; (3) interesse vital e relativamente estável nos eventos mundanos; (4) afinidade ontológica entre expectativas subjetivas e condiçóes objetivas; isto é, antecipaçóes de comportamento que, de modo geral, coadunam-se com o desenrolar habitual e rotineiro do mundo; (5) pressuposiçáo de que os acontecimentos que acabaram de ocorrer podem (e devem) acontecer novamente no futuro; (6) facticidade e plausibilidade do mundo; (7) compartilhamento de um sistema de comunicação intersubjetivo; e, por fim, (8) intercambialidade de pontos de vistas e congruência de relevâncias. Nesta forma dóxica de experimentar o mundo, existimos sob a salvaguarda daquilo que, certa feita, Giddens (2009, p. 58), ${ }^{14}$ ao citar Erik Erikson, chamou de estado de segurança ontológica. Esta pode ser sintetizada pela modalidade de agir com a qual nos relacionamos com um mundo que se mostra familiar; isto é, em seu caráter apodíctico e não problemático. ${ }^{15}$

Porém, cabe perguntar o que acontece quando a evidência habitual e rotineira da compreensão e da familiaridade para com o mundo é repentinamente suspensa - e interrompida, de modo a ir além da margem de tolerância em relação à "normalidade" do que se passa. O que sobrevém quando, em dado momento, não nos compreendemos mais, não entendemos mais o que se passa, não temos mais a devida compreensão do sentido das coisas, e o mundo se torna incerto, indeterminado, ambíguo, confuso? Ora, uma falha, uma anomalia ou um problema, cuja intensidade transgride os limites do tolerável, 
não deixam outra opção - para seguir John Dewey (1998) -, a não ser refletir e agir em uma intenção reparativa. Quando o automatismo habitual do corpo ou o arranjo rotineiro e interobjetivo (Latour, 1996) das coisas não são mais capazes de fazer tudo fluir naturalmente, ou, diante de um problema menor, de "dar conta da situação" - quer dizer, de restitui-la à sua normalidade -, ocorre uma mudança qualitativa na natureza da situação e da tonalidade afetiva própria ao organismo.

$\mathrm{Na}$ esteira de Dewey, podemos dizer que a quebra com o regime prático de ação tem por corolário a emergência de um regime em que se instaura a reflexão ou a investigação ${ }^{16}$ (inquiry). Como salienta Boltanski, trata-se da passagem do regime de ação prática para um regime reflexivo,

[...] no curso do qual a atenção dos participantes se desloca da tarefa a realizar para se virar para a questão de saber como convém qualificar o que se passa. A atenção dos participantes se orienta então na direção da própria ação em comum, de suas modalidades, de suas condiçóes de possibilidade, das formas nas quais ela se inscreve. O que se está fazendo [...] parece não mais óbvio. $\mathrm{E}$ mesmo que [...] a aparência de um acordo não seja colocada em questão, as atençóes e energias se viram para o que é preciso fazer, para fazer face às urgências da realidade, se orientando na direção [...] de saber o que de fato se faz e qual será o modo como se deve agir para que o que se faz seja feito realmente. (Boltanski, 2009, p. 107)

O regime reflexivo ou de objetivação ${ }^{17}$ seria aquele no qual o objeto ou a situação são afastados, enquanto tais, passando a ser apreendidos reflexivamente. É precisamente no desnivelamento entre a situação em sua atualização concreta e a expectativa em relação ao que deveria acontecer, que emerge o regime reflexivo. E é, ainda, por meio dele, que podemos chegar ao terceiro gesto.

Tal gesto nos importa, na medida em que nos ajuda a responder à seguinte questáo: quais as situaçôes, os momentos, as circunstâncias em que os atores apresentam reflexivamente "em ato" o que lhes é pertinente, justo, real, autêntico, etc.?
Quais as ocasióes ou os momentos em que os atores explicitam e tornam visível, aos pesquisadores, aquilo que lhes é constitutivo e elementar? Eis a importância do regime reflexivo e do terceiro gesto. $\mathrm{O}$ gesto metodológico de seleção ou enquadramento visa justamente apreender aquilo que os atores explicitam reflexivamente, quando se deparam com momentos críticos, situações de prova, provação (épreuve) ou situaçôes indeterminadas. Dos três gestos, este é, decerto, o mais pragmatista da sociologia pragmática. Trata-se de uma aposta metodológica calcada no que se pode chamar de heurística dos momentos críticos, das situaçóes indeterminadas ou de prova. Estas são ocasióes nas quais os próprios atores tendem a explicitar - transformando ou ratificando -, por meio de sua fala ou de suas açóes, os elementos que lhes são fundamentais, constitutivos e pertinentes.

A diferença em relação a Dewey é que, enquanto este faz uma filosofia das formas elementares da investigação, os sociólogos pragmáticos propóem uma sociologia das investigaçóes dos atores. No caso de Boltanski e Thévenot, trata-se, como vimos, de uma sociologia das investigações dos atores que, em meio a disputas, apelam a princípios axiológicos, visando estabelecer um acordo justo. Já no caso de Bessy e Chateauraynaud, trata-se de uma sociologia das investigaçóes dos atores, cujo modo de resolução diante de uma situação crítica implica no apelo ao princípio de realidade que rege a sua economia da percepção. $\mathrm{O}$ que esses quatro autores têm em comum é o uso estratégico de um enquadramento metodológico particular: eles apostam que, ao olhar para as situaçóes de crise, problemáticas, indeterminadas (não para o pesquisador, mas para os próprios atores pesquisados), o pesquisador tem acesso aos critérios fundamentais que presidem as ações dos atores que ele busca conhecer e que, em estado habitual e rotineiro, permanecem invisíveis, porque naturalizados e tácitos.

Em De la justification, a aposta de Boltanski e Thévenot - ao buscarem capturar as pressuposiçóes normativas dos atores, olhando não para situaçóes comuns e habituais, mas para o que eles chamam de "momentos críticos" - é de que os próprios atores, quando submetidos a um imperativo de justificação, explicitam as pressuposiçóes normativas que permanecem 
em estado implícito durante situações rotineiras e habituais. Afinal, como advertem os autores, ${ }^{18}$

as grandezas [ou valores] tornam-se particularmente proeminentes nas situaçóes de disputa, tais como se pode observá-las nas inúmeras ocasióes da vida quotidiana. Caracterizadas por uma inquietude sobre a avaliação das pessoas, esses momentos são propícios para a localização dos modos de qualificação. (Boltanski \& Thévenot, 1991, p. 26)

Em Experts et faussaires (1995), conforme vimos anteriormente, Bessy e Chateauraynaud deslocam o problema da dimensão axiológica para a dimensão ontológica. Contudo, no que diz respeito ao terceiro gesto, o raciocínio segue o mesmo de Boltanski e Thévenot, pois eles olham para as situaçóes nas quais a aparência e a realidade são indiscerníveis para as pessoas pesquisadas, com a finalidade de descrever a economia da percepção tornada visível pelo trabalho que os próprios atores empreendem quando intentam criar uma realidade sensível comum. Nessa lógica, eles afirmam que

os momentos de suspensão da ação, de falha, de início de disputa são [...] primordiais, porque, neles, os próprios atores devem reelaborar as preensóes e superar a brutal cisão entre as representações [simbólicas], de um lado, e as dobras [da matéria], de outro. (Chateauraynaud \& Bessy, 1995, p. 246)

Em suma, o mundo só se torna objeto de conhecimento (para os próprios atores pesquisados) e, por derivação, para o pesquisador que os investiga, quando nele aparece algo de problemático.

Eis porque discutir os momentos de prova (épreuve) - isto é, momentos de indefinição, que exigem e instigam um trabalho de definição da parte dos atores - é, do ponto de vista do terceiro gesto da sociologia pragmática, essencial para que o sociólogo ou o pesquisador possam levar a sério a capacidade dos atores de dizer o que para eles é real, pertinente. Assim, o terceiro gesto da sociologia pragmática pretende tirar todas as consequências não apenas do fato de que as pessoas, de tempos em tempos e de maneira relativamente regular, precisam produzir provas acerca do que é o mundo - ou daquilo que é do e no mundo -, de sua facticidade ou tangibilidade, mas também do fato de que, ao fazê-lo, elas manifestam os procedimentos e os conteúdos do que elas acreditam ser pertinente e real. Dito de outro modo, a aposta do terceiro gesto é de que a observaçáo desses momentos de indeterminação e de prova ou provação permite melhor descrever as formas por meio das quais, em face de uma exigência de verdade ou de verificação, as pessoas explicitam provas, modos de comprovaçáo que costumam estar ajustados à epistemologia prática exigida pela situação. Ora, assim como Boltanski e Thévenot observam, em De la justification (1991), a maneira como as pessoas, em situaçóes de disputa, mobilizam uma metafísica moral adequada à situação vigente, de modo a produzir um acordo, o mesmo pode ser dito em relação às concepçóes de realidade. Nas situações críticas, em que se torna confuso discernir o que é real e o que é falso, as pessoas tendem a mobilizar suas capacidades reflexivas, com o objetivo de reconduzir o estado de coisas a uma dimensão rotineira e habitual.

É preciso enfatizar que essa heurística dos momentos críticos se desdobra em várias pesquisas, na constelação pragmática da sociologia: seja aquela do mapeamento de controvérsias de Latour (2016), da balística sociológica de Chateauraynaud (2011), das arenas públicas de Daniel Cefaï (2017), da tradição pragmatista de Dewey - sobretudo em seu livro The Public and its Problems (1927) - ou, ainda, na relevância que Boltanski e Clavérie (2007) atribuem aos casos (affaires). Todos estes trabalhos compartilham uma sensibilidade em torno da heurística das situaçóes em que ocorre uma disrupção de alguma ordem para os atores, obrigando-os a um trabalho de resolução e, com isso, de explicitação dos fundamentos de sua ação.

\section{Conclusão}

O uso dos três gestos, na caracterização do que entendo como constitutivo de um movimento recente na sociologia francesa, ou da sociologia pragmática tal como ela vem sendo atualizada em outros países, 
é heuristicamente sugestivo, não só em relação à dimensão explicitativa e escolar dos fundamentos dessa sociologia, mas sobretudo no que diz respeito à proposição de contribuiçóes para um esboço de uma outra agenda para a teoria social contemporânea. Foi essa a minha intenção com o presente artigo. Por isso, é importante ressaltar, em particular, não apenas o que os aludidos gestos trazem de importante, mas também como eles ajudam a introduzir novos desafios e questóes para a sociologia.

Neste sentido, cabem algumas perguntas, seguindo o contorno dos gestos: (1) Como é possível fazer uma sociologia contemporânea, que respeite a introdução progressiva de novas entidades na composiçáo do social (sejam elas, animais, objetos, entidades nâo humanas como deuses, encantados, espíritos, etc.)?; (2) Como ser capaz de, respeitando essa pluralidade radical de partida, abrir-se maximamente à experiência daqueles cuja tarefa de conhecer nos colocamos?; (3) Como é possível observar o que é fundamental e pertinente para aqueles a quem delegamos a capacidade de produzir conhecimento sobre o mundo, a realidade, a justiça, etc.?

Penso que tais perguntas ajudam a reposicionar, na teoria social, as questóes comumente associadas ao "novo movimento teórico" (Alexander, 1987). Segundo Alexander, por volta do final da década de 1980, a sociologia vivia um momento crucial, em que diversos autores de distintas constelaçóes nacionais (Anthony Giddens, na Inglaterra; Jürgen Habermas, na Alemanha; Randall Collins, nos Estados Unidos; e Pierre Bourdieu, na França, para ficar entre apenas alguns dos mais conhecidos) passaram a buscar sínteses, ao invés de posições polêmicas, entre abordagens parciais que ora enfatizavam o papel macrossocial das estruturas, ora sublinhavam o papel microssociológico do indivíduo ou da agência. Era esta a agenda em curso: a superação de oposiçóes já instituídas nos tradicionais debates da sociologia, tais como indivíduo versus sociedade, micro versus macro e agência versus estrutura. A teoria do habitus de Bourdieu, da estruturação de Giddens, do agir comunicativo de Habermas e das cadeias de interação ritual de Collins buscaram, cada qual ao seu modo, e de forma engenhosa, propor um caminho para a realização de uma nova síntese.
Contudo, é possível afirmar, hoje, que diversos elementos e questóes não foram contemplados - ou mesmo deixados de lado - pelos aludidos autores. Há algum tempo, o que foi produzido pelo "novo movimento teórico" não corresponde aos desafios do mundo hodierno, nem, é claro, da sociologia contemporânea. Novas questôes emergiram e, longe de esgotá-las no espaço deste artigo, salientei, ao menos, duas. A primeira, oriunda das críticas pós-humanistas, esteve atrelada à capacidade de a sociologia incorporar à sociedade dimensôes outras do que aquelas dos humanos. Seja enfatizando o papel dos objetos (Conein, Dodier \& Thévenot, 1993; Latour, 1996), dos dispositivos (Deleuze, 1989; Foucault, 2001; Agamben, 2007; Akrich, Callon \& Latour, 1988) e dos artefatos sociotécnicos (Akrich, 1987; Latour, 1985; 1989), como também do de outras entidades não humanas, como os deuses (Clavérie, 2003; Descola, 2005; Piette, 1999), animais (Bimbenet, 2011), e até Gaia (Chakrabarty, 2009; Latour, 2015), o ponto passou a ser o de como podemos expressar e descrever o papel actancial de toda e qualquer entidade - humana ou não humana -, no mundo social.

A segunda questão, ligada à primeira, tem a ver com críticas, advindas sobretudo da antropologia, de que a sociologia estaria desde sempre comprometida com o mais basilar dos grandes divisores "moderno" (Latour, 1995) ou "naturalista" (Descola, 2005): a saber, aquele entre natureza e cultura. Ainda que os teóricos da síntese tenham feito progressos na diluição de oposiçóes, como indivíduo e sociedade, agência e estrutura, micro e macro, eles não teriam contribuído para forjar um conceito de sociedade ou de social, que não fosse tributário da divisão a priori entre uma ordem natural das coisas (normalmente, deixada ao encargo da química ou biologia e outras ciências mais "duras") e outra ordem social dos humanos (sobre a qual a sociologia e as outras ciências humanas devem falar). É neste sentido, que os três gestos analisados anteriormente procuraram não só ir além da grande problemática do "novo movimento teórico" estabelecido por Alexander, como também oferecer uma resposta possível à seguinte pergunta: como propor uma teoria social capaz de incorporar ao mundo social as entidades não humanas, sem ficar, 
ao mesmo tempo, prisioneira da famosa divisão entre natureza e cultura?

Espero, com o exercício de exposição teórica e metodológica da sociologia pragmática, ter sido capaz tanto de apontar novas questóes, quanto de incentivar a teoria social, a partir de três gestos, a caminhar na direção de novos rumos.

\section{AGRADECIMENTOS}

Este artigo foi originalmente escrito como um paper apresentado no grupo temático de Teoria Sociológica do $19^{\circ}$ Congresso Brasileiro de Sociologia. Sou grato aos organizadores pela oportunidade de tê-lo apresentado e debatido, sob a moderação de Raquel Weiss. Minha gratidão se estende, em particular, às atentas leituras e comentários de Samantha Sales e Gabriel Peters. Também devo dizer que a versão final deste texto se beneficiou muito dos pareceristas anônimos da presente revista.

\section{Notas}

1 Deleuze, Gilles. “A quoi reconnait-on le structuralisme ?”, in L'île déserte et autres textes : Textes et entretiens 1953-1974, Paris, Les Éditions de Minuit, coll. Paradoxe, 2002, p. 238-296.

2 É importante frisar que concebo a sociologia pragmática como uma constelaçáo intelectual que contempla um conjunto de autores bastante heterogêneos, entre os quais vale mencionar Bruno Latour, Michel Callon, Luc Boltanski, Laurent Thévenot, Nathalie Heinich, Nicolas Dodier, Cyril Lemieux, Francis Chateauraynaud, Daniel Cefaï e Louis Quéré. Exploro, portanto, a tradição francesa da constelação pragmática da sociologia, deixando de lado um embate mais direto com outras vertentes pragmáticas da sociologia, como aquela proposta por Hans Joas (1993), no livro Pragmatism and Social Theory, em que o autor tenta superar os modelos dominantes de "ação racional" e "açâo normativa" em favor de um terceiro, cujo objetivo maior é revelar o caráter criativo da ação humana. Deixo claro que, no presente artigo, trato a noção de sociologia pragmática em termos impessoais, ideal típicos, e estou mais preocupado em extrair certas proposiçóes gerais de um conjunto de autores que se inserem nessa constelação da sociologia (Dosse, 2003), do que em investigar diferenças internas à própria tradição. Portanto, não tenho a intenção de estabelecer fronteiras entre, por exemplo, a filosofia pragmatista americana e a sociologia pragmática francesa; ou entre o pragmatismo clássico e a pragmática filosófica de influência wittgensteiniana, etc.

3 Sou consciente de que há, em Durkheim, uma sensível mudança de ênfase, no curso de sua obra, e que o argumento ontológico se exprime com mais clareza, em seus primeiros trabalhos. Como é possível verificar, no clássico estudo que Steven Lukes dedicou ao sociólogo francês (Lukes, 1973), a autoridade moral da sociedade tende a aparecer, sobretudo no primeiro Durkheim, mais sob o aspecto da coerçáo exterior; ao passo que, no último Durkheim, ela assume mais um formato de ideal moral internalizado. Trata-se de uma nuance importante de sua obra, mas que não abole, em minha opiniāo, a importância do argumento ontológico para a dimensão metafísica do conceito de sociedade.

4 O ponto fundamental, entendo, é mostrar como Durkheim mantém certa estrutura do raciocínio do argumento ontológico, ao tentar (com)provar a existência da sociedade. Adianto que o essencial consistirá em mostrar como ele chega à conclusão de que a sociedade é um ser de tal modo potente, geral, exterior e coercitivo (para fazer aqui menção às características que, em As regras do método sociológico (1999[1895]), ele descreve como intrínsecas ao fato social), que mesmo que uma representação individual possa (tentar) negar a sua existência, ela se imporá por si mesma.

5 Trata-se, portanto, de um ajuste a uma realidade que existe independentemente da sua consciência, e que exerce sobre a pessoa um poder coercitivo. A demonstração da existência independente e autônoma dos códigos, regras e regulamentos reside no fato de que, caso a pessoa contrarie aquilo que se faz normativamente presente por meio dos mesmos, ela experimentará a autoridade pela manifestação de uma sanção. Este é, para Durkheim, o modo de manifestação privilegiado da sociedade: a coerção imposta pela autoridade é um signo exterior de sua força superior sempre existente, que, quando contradita, impóe-se aos indivíduos na forma de uma punição ou medida repressiva.

6 Vale notar como, em diversos aspectos, a argumentação do sociólogo francês se assemelha àquela de Descartes sobre a prova ontológica. Assim como o Deus cartesiano, a sociedade de Durkheim busca um argumento que, mesmo o individualista mais intransigente (em Descartes, o ateu mais indecoroso), náo pode negar: a existência de representaçôes de forças superiores. É possível, a partir deste fio condutor, colocar a perspectiva de Descartes em estreita relação com a de Durkheim. Se o primeiro afirma que a causa não pode ser maior que o efeito, o segundo assevera que "o indivíduo não saberia, sem milagre, nascer de algo menor [que ele]”. (1897, p. 359); se Descartes 
declara que tem a ideia de Deus infinito, Durkheim constata que o "indivíduo tem a ideia de forças que o ultrapassam [...] infinitamente". (p. 352); Descartes diz que a realidade objetiva, enquanto representação da ideia de Deus, tem mais ser do que a realidade formal humana enquanto substância, enquanto Durkheim, de modo análogo, replica que a representaçáo de tais forças (que ultrapassam infinitamente o indivíduo) tem mais realidade do que o indivíduo que as representa. Por fim, se Descartes conclui, com tal raciocínio, que "logo, Deus existe", Durkheim, por sua vez, termina seu encadeamento de raciocínios afirmando que existe alguma coisa superior e exterior aos indivíduos (Deus ou a Sociedade).

7 Todas as citaçóes foram traduzidas pelo autor do presente artigo.

8 Em Bourdieu, a sociedade continua a ser uma espécie de equivalente funcional de Deus, e assim afirma, em suas Meditaçôes pascalianas (2001), que "Deus não é nada mais que a sociedade" (p. 56). Contudo, Bourdieu só faz esse movimento "objetivista" ou "neo-objetivista" (Peters, 2013) para, em seguida, operar um deslocamento importante em relaçáo ao conceito de sociedade, acrescentando a ele a ideia sartreana, muito bem explorada por Gabriel Peters (2012), de que "o inferno são os outros", e de que "o homem é o lobo do homem". Ao assumir uma antropologia filosófica "existencialista", além de introduzir no coração da ordem social uma lógica agonística de e por reconhecimento (arbitrário), Bourdieu - por meio de uma série de conceitos vinculados ao que Paul Ricoeur (2013) chamou de "hermenêutica da suspeita", tais como violência simbólica e dominação -, faz o deus durkheimiano virar uma espécie de diabo ardiloso e enganador. Se é verdade que, assim como em Durkheim, Bourdieu sustenta que todos estamos submetidos à força e à potência do social e da sociedade, é igualmente verdade, todavia, que ele institui no coração do social a lógica do arbitrário e afirma que: "[...] o homem é um ser sem razão de ser. É a sociedade, e apenas ela, que dispensa, em diferentes graus, as justificaçōes e as razões de existir; é ela que, produzindo os negócios ou posições que se dizem "importantes", produz os atos e os agentes que se julgam "importantes", para eles mesmos e para os outros, personagens objetiva e subjetivamente assegurados de seu valor e, assim, subtraídos à indiferença e à insignificância. Existe, apesar do que diz Marx, uma filosofia da miséria, que está mais próxima da desolação dos velhos marginalizados e derrisórios de Beckett, do que do otimismo voluntarista tradicionalmente associado ao pensamento progressista. Miséria do homem sem Deus, dizia Pascal. Miséria do homem sem missão nem consagração social. De fato, sem chegar a dizer, como Durkheim, que "a sociedade é Deus", eu diria: Deus não é nada mais que a sociedade. O que se espera de Deus nunca se obtém senão na sociedade, que tem o monopólio do poder de consagrar, de subtrair à fatuidade, à contingência, ao absurdo; porém - e aí está a antinomia fundamental -, apenas de maneira diferencial, distintiva. Todo sagrado tem o seu profano complementar, toda distinção produz sua vulgaridade e a concorrência pela existência social conhecida e reconhecida, que subtrai à insignificância; é uma luta de morte pela vida e pela morte simbólicas. "[...] O julgamento dos outros é o julgamento derradeiro; $e$ a exclusão social, a forma concreta do inferno e da danação. É porque o homem éum Deus para o homem que o homem é também o lobo do homem". (Bourdieu, 1997, p. 56-58, grifos do presente autor). Se, para Bourdieu, na esteira do objetivismo do social durkheimiano, é verdade que "o que se espera de Deus nunca se obtém senáo na sociedade, que tem o monopólio do poder de consagrar", é igualmente verdade que é preciso que algum ser nos subtraia à fatuidade, à contingência e ao absurdo. Ora, isso significa dizer que, em sua antropologia filosófica, Bourdieu permanece arraigado à antropologia sartreana, a qual, em muitos aspectos, ele pretendeu criticar.

9 Logo na apresentação da aludida obra, Latour se pergunta: "O que acontece quando nada é reduzido a outra coisa? O que acontece quando suspendemos nosso conhecimento do que é a força? O que acontece quando nós não sabemos como o jeito delas se relacionarem umas com as outras está mudando? $\mathrm{O}$ que acontece quando desistimos do fardo, da paixão, da indignação, da obsessão, da chama, da fúria, do objetivo cintilante, do excesso, do desejo insano de reduzir tudo?". (Latour, 1984, p. 175).

10 Isso não quer dizer que o mundo - e a vida social, no sentido clássico do termo - seja um puro caos: o pluriverso é constituído por planos de consistência (mais tarde, no caso dos modernos, Latour falará, inspirado pela ontologia de Étienne Souriau, em modos de existência), que são todos produzidos localmente e provisoriamente pelas interaçôes da própria multidão de actâncias entre si.

11 Por isso, diz Latour, ainda em seu tratado metafísico sobre as irreduções: "só existem provas de força, de fraqueza. Ou, posto mais simplesmente, só existem provas. Esse é meu ponto de partida: um verbo, 'provar' [...] Só existem provas (de força, de fraqueza) porque nada é, por si mesmo, redutível ou irredutível a qualquer outra coisa. O que não é redutível ou irredutível tem que ser testado, contado e mensurado. Não há outro jeito". (Latour, 1984, p. 177).

12 Manuel De Landa assim descreve a ontologia plana: "[...] enquanto uma ontologia baseada em relaçóes entre tipos gerais e instâncias particulares é hierárquica, cada nível representando uma categoria ontológica diferente 
(organismo, espécie, gênero), uma abordagem em termos de partes interagentes e conjuntos emergentes conduz a uma ontologia plana, feita exclusivamente de indivíduos únicos e singulares, diferindo em escala espaço-temporal mas não em estado ontológico”. (De Landa, 2002, p. 47).

13 Este é, portanto, o primeiro princípio que subjaz à sociologia pragmática: a substituição do conceito durkheimiano clássico de sociedade, pela profusão de associações entre termos heterogêneos. Não é por acaso, que Latour, em Reagregando o social (2012), faz a recuperação da obra de Gabriel Tarde, para quem há sociedades de moléculas, amebas, animais e humanos.

14 Nas palavras do sociólogo inglês, "a vida comum do dia-a-dia - em maior ou menor grau, de acordo com o contexto e os caprichos da personalidade individual - envolve uma segurança ontológica, que expressa uma autonomia do controle corporal no âmbito das rotinas previsiveis". (Giddens, 2009, p. 58).

15 Trata-se, aqui, da experiência mais banal possível em que nos inserimos; a saber, um regime de ação rotineiro, voltado para o exercício de uma orientação prática e não reflexiva. Nele, a ação em comum é desdobrada em função de tarefas práticas a realizar. São as disposições e os hábitos corporais ou dispositivos; ou seja, objetos materiais ou simbólicos, que auxiliam na coordenação da ação individual ou coletiva (e.g. código de trânsito, quebra-molas, placas de orientação, GPS, etc). A confiança é o sentimento que melhor define o que vige nestas situaçóes; razão pela qual, em momentos de ruptura - como Garfinkel (1967, p. 198) nos mostrou -, os sentimentos que mais afloram indicam o seu avesso; a saber, a "ansiedade e a indignação". Outra característica comum a este regime dóxico de ação rotineira e habitual é uma tolerância hermenêutica frente às rupturas, falhas e anomalias. Boltanski, em De la critique, nos lembra que, em tal regime, "as pessoas cooperam ativamente para manterem-se longe da inquietude que as ameaça, ignorando as diferenças de interpretaçáo sobre o que se passa e, sobretudo, fechando os olhos a propósito das falhas que podem introduzir fatores de incerteza”. (Boltanski, 2009, p. 99).

16 Dewey afirma que "a reflexão ocorre apenas em situação qualificada por sua incerteza, [quando há] alternativas possíveis, questionamentos, busca, hipóteses, tentativas ou experimentos cujo teste são dignos de serem pensados". (Dewey, 1958, p. 68). Ele enfatiza que a reflexão ou a investigação são o que emerge, quando o organismo se depara com uma situação indeterminada e desconcertante. Segundo o autor, saímos do regime dóxico de ação, precisamente quando "há uma situação conturbada, desconcertante e intricada, em que a dificuldade é, por assim dizer, espalhada por toda a situação, infectando-a como um todo. [...] Na verdade, sabemos exatamente qual é o problema encontrando uma saída e resolvendo o problema”. (Dewey, 1998[1933], p. 140).

17 Ou da passagem para o que Bessy e Chateauraynaud chamam de "regime de objetivação": "As perturbaçóes suscitadas pelas coisas provêm, assim, de três fontes que podem ser conjugadas: a entrada em um mundo desconhecido ou pouco familiar que envolve de modo intenso o dispositivo sensorial; uma mudança de dispositivo de objeto que [...] se encontra, por assim dizer, em suspensão entre vários universos; uma ruptura, um estado crítico, uma catástrofe que [...] altera ou ameaça a ação rotineira e que conduz à presença radical dos corpos. Nesses momentos de perturbaçáo, se desenvolve a divisão entre dois regimes que nós chamamos de regime de objetivação e regime de captura”. (1995, p. 246).

18 A hipótese é de que a concentração, nos momentos críticos que exigem dos atores uma atividade axiológica para a sua resolução, permite não só fazer jus a uma sociedade cujos princípios de justificação tornam-se complexos (Derouet, 1992), mas também ter acesso aos princípios que norteiam a ação axiologicamente orientada dos atores: "Essa orientação teórica que supóe capturar a açáo em sua relação com a incerteza, tem por consequência, no nível do método de observação, o enfoque da pesquisa nos momentos de disputa e de crítica que constituem as cenas principais dessa obra. Aliás, a escolha de estudar prioritariamente esses momentos nos parece particularmente adaptada ao estudo de uma sociedade onde a crítica ocupa um lugar central e constitui um instrumento principal de que dispóem os atores para experimentar a relação do particular e do geral, do local e do global”. (Boltanski \& Thévenot, 1991, p. 31).

\section{BIBLIOGRAFIA}

AKRICH, Madeleine. (1987), "Comment décrire les objets techniques?”. Techniques et Culture, 9: 49-64.

AKRICH, Madeleine; CALLON, Michel \& LATOUR, Bruno. (1988), "À quoi tient le succès des innovations? 1. L'art de l'intéressement". Annales des mines: Gérer et Comprendre, 11: 4-17.

ANSELMO de Cantorbéry. (1986), Monologion. Prosologion, Paris, Ed. du Cerf.

AGAMBEN, Giorgio. ([2006] 2007), Qu'est-ce qu'un dispositif?, Paris, Payot et Rivages.

ARCHER, Margaret. (2003), Structure, Agency and the Internal Conversation, Cambridge, Cambridge University Press. 
BACHELARD, Gaston. ([1949] 1986), Le rationalisme appliqué, Paris, P.U.F.

BACHELARD, Gaston. ([1938] 1993), La formation de l'esprit scientifique. Contribution à une psychanalyse de la connaissance, Paris, Vrin.

BACHMANN-MEDICK, Doris. (2016), Cultural Turns. New Orientations in the Study of Culture, Berlim, De Gruyter.

BIMBENET, Etiénne. (2011), L'animal que je ne suis plus, Paris, Gallimard.

BOLTANSKI, Luc. (1990), L'amour et la justice comme compétences: Trois essais de sociologie de l'action, Paris, Métailié.

BOLTANSKI, Luc \& THÉVENOT, Laurent. (1991), De la justification, Paris, Gallimard.

BOLTANSKI, Luc \& CLAVÉRIE, Elisabeth. (2007), "Du monde social en tant que scène d'un procès", in N. Offernstadt; S. Van Damme (org.). Affaires, scandales et grandes causes: De Socrate à Pinochet, Paris, Stock, 395-452.

BOURDIEU, Pierre. (1973), Jean-Claude Chamboredon, Jean-Claude Passeron, Le Métier de Sociologue, Paris, École Pratique des Hautes Études, Mouton and Borda.

BOURDIEU, Pierre. (1997), A miséria do mundo. Traduzido por Mateus S. Soares Azevedo; Jaime A. Clasen; Sérgio H. de Freitas Guimarães; Marcus Antunes Penchel; Guilherme J. de Freitas Teixeira; Jairo Veloso Vargas. Petrópolis, Vozes.

BOURDIEU, Pierre. (2001), Meditaçóes Pascalianas. Traduzido por Sérgio Miceli. São Paulo, Bertrand Brasil.

CEFAI, Daniel. (2017), “Públicos, problemas públicos, arenas públicas... O que nos ensina o pragmatismo". Revista Novos Estudos do Cebrap, 107: 187-213.

CHAKRABARTY, Dipesh. (2009), "The Climate of History: Four Theses”. Critical Inquiry, 35, 2: 197-222.

CHATEAURAYNAUD, Francis. (1991), La faute professionnelle: une sociologie des conflits de travail, Paris, Métaillé.

CHATEAURAYNAUD, Francis \& BESSY, Christian. (1995), Experts et faussaires: Pour une sociologie de la perception, Paris, Métaillé.
CHATEAURAYNAUD, Francis \& TORNY, Didier. (1999), Les Sombres précurseurs. Une sociologie pragmatique de l'alerte et du risque, Paris, Éditions de l'École des Hautes Études en Sciences Sociales.

CLAVERIE, Élisabeth. (2003), Les guerres de la vierge. Une anthropologie des apparitions, Paris, Gallimard.

CONEIN, Bernard; DODIER, Nicolas; THEVENO, Laurent (org.). (1993), Les objets dans l'action: De la maison au laboratoire, Paris, Éditions de l'Ehess.

CORREA, Diogo Silva. (2015), Anjos de fuzil: Uma etnografia das relaçóes entre tráfico de drogas e igreja evangélica. Tese de doutorado. Universidade do Estado do Rio de Janeiro, Rio de Janeiro/École des Hautes Études en Sciences Sociales, Paris.

CORREA, Diogo Silva \& DIAS, Rodrigo de Castro. (2016), "A crítica e os momentos críticos: De la justification e a guinada pragmática na sociologia francesa”. Mana, 22, 1: 67-99.

CRAHAY, Franz. (1949), "L'argument ontologique chez Descartes et Leibniz et la critique kantienne". Revue Philosophique de Louvain, Troisième série, 47, 16: 458-468.

DE CASTRO, Rodrigo. (2016), Gestos, exemplares: Sobre alguns modos de apreensáo gestual da exemplaridade. Tese de doutorado. Universidade Federal do Rio de Janeiro, Rio de Janeiro.

DELEUZE, Gilles. (1989), Qu'est-ce qu'un dispositif?, in A. Strowel (org.), Michel Foucault philosophe. Rencontre internationale, Paris, Seuil: 185-195

DELEUZE, Gilles. (2002), "A quoi reconnait-on le structuralisme?”, in L'île déserte et autres textes : Textes et entretiens 1953-1974, Paris, Les Éditions de Minuit, coll. Paradoxe, pp. 238-296

DE LANDA, Manuel. (2002), Intensive Science and Virtual Philosophy. Londres and Nova York, Continuum.

DEROUET, Jean-Louis. (1992), École et justice, Paris, Métailié.

DESCARTES, René. (1996), Euvres complètes. Ed. Ch. Adam, Vrin, Paris.

DEWEY, John. (1927), The Public and Its Problems, Nova York, Swallow Press.

DEWEY, John. (1998), "The Pattern of Inquiry", in L. Hickman \& T. Alexander (org.), The 
Essential Dewey: v. II: Ethics, Logic, Psychology, Bloomington, Indiana University Press.

DODIER, Nicolas, \& BARBOT, Janine. (2017), A força dos dispositivos. Sociedade e Estado, 32(2): 487-518.

DURKHEIM, Émile. ([1893]1991), De la division du travail social: étude sur l'organisation des sociétés supérieures, Alcan, Paris, PUF.

DURKHEIM, Émile. ([1912] 1968), Les formes élémentaires de la vie religieuse: Le système totémique en Australie, Paris, PUF.

DURKHEIM, Émile. (1950), Leçons de Sociologie: physique des mœurs et du droit, Paris, PUF.

EMERSON, Robert \& MESSINGER, Sheldon. (1977), "The Micro-Politics of Trouble”. Social Problems, 25: 121-134.

FRANCO, Ana Paula Perrota. (2015), Humanidade estendida: a construção dos animais como sujeito de direitos. Tese de Doutorado. Universidade Federal do Rio de Janeiro, Rio de Janeiro.

GOFFMAN, Erving. (2012), Os quadros da experiência social: Uma perspectiva de análise. Traduzido por Gentil Avelino Titton. Petrópolis, Vozes.

GARCIA, Tristan. (2010), Forme et objet. Un traité des choses, Paris, Puf.

GARFINKEL, Harold. (1963), "A Conception of, and Experiments with, "Trust" as a Condition for Stable Concerted Actions", in O.J. Harvey (org.), Motivation and Social Interaction, Nova York, Ronald Press: 187-238.

GARFINKEL, Harold. (1967), Studies in Ethnomethodology. 2a edição, Londres, Routledge Press.

GARFINKEL, Harold. ([1967] 2018), Estudos em etnometodologia. Traduzido por Adauto Vilella; Aline Domingues de Paiva; Bráulio de Oliveira Silveira; Clara Peron da Silva Guedes; Diogo Figueiras Britto; Filipe Augusto Noronha; Luy Braida Ribeiro Braga; Paulo Cortes Gago; Raquel Santos Lombardi; Raul Francisco Magalhães; Ricardo A. Rosenbush, Petrópolis, Editora Vozes. GUSFIELD, Joseph R. (1981), The Culture of Public Problems: Drinking, Driving and the Symbolic Order., Chicago, The University of Chicago Press.
HABERMAS, Jürgen. (1984), The Theory of Communicative Action. V. 1. Reason and the rationalizalion of society, Boston, Beacon Press.

HABERMAS, Jürgen. (1987), The Theory of Communicative Action. V. 2. Lifeworld and system: A critique of functionalist reason, Boston, Beacon Press.

KARSENTI, Bruno. (2002), Retour sur le débat entre Durkheim et Tarde, in C. Chauviré \& A. Ogien (org.), La Regularité - habitude, disposition et savoir-faire dans l'explication, Paris, Ed. EHESS.

LAHIRE, Bernard. (2005), "Patrimônios individuais de disposiçôes: Para uma sociologia à escala individual". Sociologia, problemas e práticas, 49: $11-42$.

LATOUR, Bruno. (1985), "Les “vues” de l'esprit. Une introduction à l'anthropologie des sciences et des techniques". Culture Technique, 14: 6-29.

LATOUR, Bruno. (1986), The power of association, in J. Law (org.), Power, action belief: A new sociology of knowledge?, Londres, Routledge and Kegan Paul.

LATOUR, Bruno. ([1987] 1989), La science en action., Paris, La Découverte.

LATOUR, Bruno. (1994), Jamais fomos modernos: ensaio de antropologia simétrica. Tradução de Carlos Irineu da Costa. 1a edição, Rio de Janeiro, Editora 34.

LATOUR, Bruno. (1996), "On interobjectivity". Mind, Culture, and Activity, 3, 4: 228-245.

LATOUR, Bruno. (2012), Reagregando o social: Uma introdução à teoria do ator-rede. Traduzido por Gilson César Cardoso de Sousa. Salvador/ Florianópolis, UFBa/Edusc.

LATOUR, Bruno. (2015), Face à Gä̈a: Huit conférences sur le Nouveau Régime Climatique, Paris, La Découverte.

LATOUR, Bruno. (2016), Cogitamus: Seis cartas sobre as humanidades científicas, São Paulo, Editora 34.

PETERS, Gabriel. (2012), “O social entre o céu e o inferno: A antropologia filosófica de Pierre Bourdieu”, Tempo Social, São Paulo, 24, 1: 229-262.

PETERS, Gabriel. (2013), Habitus, reflexividade e neo-objetivismo na teoria da prática de Pierre 
Bourdieu. Rev. Bras. Ci. Soc. [online]. 28, 83: 48-71. Disponível em: http://www.scielo.br/ pdf/rbcsoc/v28n83/04.pdf, consultado em 15/03/2019.

PETERS, Gabriel. (2017), A ordem social como problema psíquico: Do existencialismo sociológico à epistemologia insana, São Paulo, Annablume.

RICOEUR, Paul. (2013), Cinq études herméneutiques, Genebra, Labor et Fides.

ROUSSEAU, Jean-Jacques. (1985), Devaneios de um caminhante solitário. Traduzido por Julia da Rosa Simões. São Paulo, Pocket LMP.

SALMON, Gildas. (2016), "On Ontological Delegation”, in P. Charbonnier, G. Salmon \& P. Skafish (org.), Comparative Metaphysics: Ontology
After Anthropology, Lanham, Maryland, Rowman \& Littlefield International: 41-60.

VANDENBERGHE, Frederic. (2017), "A sociologia na escala individual [1], por Frédéric Vandenberghe". Blog do Sociofilo. Disponível em: https:// blogdosociofilo.com/2017/06/13/a-sociologia-naescala-individual-1-por-frederic-vandenberghe/, consultado em 05/02/2019.

VANDENBERGHE, Frederic. (2019), "A sociologia na escala individual [2], por Frédéric Vandenberghe". Blog do Sociofilo. Disponível em: https:// blogdosociofilo.com/2017/06/19/a-sociologia-naescala-individual-2-por-frederic-vandenberghe/, consultado em 15/02/2019. 


\section{NOVOS RUMOS DA TEORIA SOCIAL A PARTIR DE TRÊS GESTOS DA SOCIOLOGIA PRAGMÁTICA}

\section{Diogo Silva Corrêa}

Palavras-chave: Sociologia pragmática; Teoria social; Sociologia contemporânea; Ontologia; Pragmatismo.

O presente artigo busca, por meio da descrição dos contornos de três gestos próprios à sociologia pragmática, trazer novas questôes para a teoria social, que escapem daquelas estabelecidas pelo "novo movimento teórico", tal como definido por Jeffrey Alexander. Por meio da descrição do gesto metafísico de inversáo da sociologia clássica durkheimiana, pretendo responder como é possível fazer uma sociologia contemporânea que respeite a introdução progressiva de novas entidades na composiçáo do social (sejam elas, animais, objetos, e entidades não humanas, de modo geral). Por meio da descrição do gesto epistemológico de delegação, ambiciono dar conta do desafio de tornar a sociologia capaz de abrir-se maximamente àqueles cuja experiência nos colocamos como tarefa conhecer. Por fim, por meio do gesto de enquadramento metodológico das situaçôes indeterminadas, problemáticas e dos momentos críticos (para os atores pesquisados), tento responder à questão de como é possível observar o que é fundamental e pertinente para aqueles a quem delegamos a capacidade de produzir conhecimento sobre o mundo, a realidade, a justiça, etc. Espero, com esse exercício de exposição teórica e metodológica da sociologia pragmática, contribuir para a introduçáo, na teoria social, de ângulos não contemplados pelo novo movimento teórico.

\section{NEW SOCIAL THEORY DIRECTIONS FROM THREE PRAGMATIC SOCIOLOGY GESTURES}

\section{Diogo Silva Corrêa}

Keywords: Pragmatic sociology; Social theory; Contemporary sociology; Ontology; Pragmatism.

By describing the outlines of three specific pragmatic sociology gestures, this article seeks to bring new issues to social theory, which escape those established by the "new theoretical movement" as defined by Jeffrey Alexander. By describing the metaphysical operation of the inversion of classical Durkheimian sociology, I intend to answer how the creation of a contemporary sociology that respects the progressive introduction of new entities in the composition of the social (be they animals, objects and general non-human entities) is possible. Through the description of epistemological gesture of delegation, I aim to address the challenge of making sociology capable of opening itself to the most to those whose experiences we place as a task to understand. Finally, by means of the gesture of methodological framing of undetermined, problematic situations and critical moments (for the surveyed actors), I attempt to answer the question of how it is possible to observe what is essential and pertinent to those to whom we delegate the capacity to produce knowledge about the world, about reality, and justice, among others. I hope, with this theoretical and methodological exposure of pragmatic sociology exercise, to contribute to the introduction, in social theory, of angles not covered by the new theoretical movement.

\section{NOUVELLES ORIENTATIONS DE LA THÉORIE SOCIALE À PARTIR DE TROIS GESTES DE LA SOCIOLOGIE PRAGMATIQUE}

\author{
Diogo Silva Corrêa
}

Mots-clés: sociologie pragmatique; théorie sociale; sociologie contemporaine; ontologie; pragmatisme.

Sur la base d'une approche générale de trois gestes spécifiques de la sociologie pragmatique, cet article vise à apporter à la théorie sociale des questions qui échappent $\mathrm{au}$ " nouveau mouvement théorique » tel que défini par Jeffrey Alexander. La description du renversement métaphysique de la sociologie classique durkheimienne vise à montrer qu'il est possible d'avoir une théorie contemporaine qui respecte l'introduction progressive des nouvelles entités dans la composition du social (qu'il s'agisse d'animaux, d'objets et, plus généralement, d'entités non humaines). La description de l'épistémologie de délégation a pour objectif d'amener la sociologie capable de s'ouvrir le plus possible à ceux dont nous cherchons à connaître l'expérience. Enfin, la description du cadre méthodologique des situations indéterminées et problématiques, ainsi que des moments critiques (pour les acteurs eux-mêmes), souligne l'importance d'observer ce qui est fondamental et pertinent pour les personnes à qui nous déléguons la capacité de produire des connaissances sur le monde, la réalité, la justice, etc. Avec cet exposé théorique et méthodologique inspiré de la sociologie pragmatique, nous espérons contribuer à l'introduction, dans la théorie sociale, d'approches jusqu'à présent non envisagées par le nouveau mouvement théorique. 